\title{
Mechanism of Killing of Giardia lamblia Trophozoites by Complement
}

\author{
Masako Deguchi,* Frances D. Gillin, ${ }^{\star}$ and Irma Gigli* \\ Division of Dermatology, Department of Medicine, ${ }^{*}$ and Division of Infectious Diseases, Department of Pathology, ${ }^{\ddagger}$ University of \\ California, San Diego, School of Medicine, San Diego, California 92103
}

\begin{abstract}
Only antibodies of the IgM class support the lytic effect of complement on Giardia lamblia (GL). We sensitized GL trophozoites (SGL) at $4^{\circ} \mathrm{C}$ with serum containing anti-GL antibodies or IgM purified from this serum, and either normal human serum (NHS), complement 2-deficient human serum (C2d-HS), or C4-deficient guinea pig serum was used as source of complement. SGL were killed by NHS (86\%) and by the deficient sera (50 and 40\%, respectively), suggesting activation of the alternative pathway. However, the reaction was inhibited by Mg-EGTA. These observations led to studies of the role of $\mathrm{Cl}$. The lytic effect of NHS and C2d-HS on SGL was abolished by immunochemically depleting $\mathrm{C} 1$ from these sera, and reconstituted by adding purified C1q plus C1r and C1s. Factor B-depleted C2d-HS also lost its capacity to mediate killing, but reconstitution with factor B led to a dose-dependent increase in the killing of SGL. We next investigated the participation of the membrane attack complex in this system. SGL carrying C5b to $\mathbf{C 7}$ were lysed when incubated with $\mathrm{C8}$ alone (56\%); the addition of $\mathrm{C} 9$ further increased killing (98\%), while $\mathrm{C} 9$ in the absence of $\mathrm{C} 8 \mathrm{had}$ no effect. We concluded that although activation of the classical pathway produces lysis of SGL, lysis may also proceed through a unique pathway of complement activation that requires $\mathrm{Cl}$ and factor $B$, but is independent of $C 4$ and C2. Lysis of SGL can be accomplished by $\mathrm{C} 5 \mathrm{~b}$ to $\mathrm{C} 8$ in the absence of $\mathrm{C}$.
\end{abstract}

\section{Introduction}

Giardia lamblia $(\mathrm{GL})^{1}$ is an important cause of gastrointestinal symptoms and malabsorption in the world population (1). Both severity and duration of giardiasis are extremely variable. Nevertheless, the mechanism(s) of host defense against this intestinal protozoan parasite are still unclear. Although both human cellular $(2,3)$ and humoral $(1,4-7)$ host response(s) to GL have

This work was presented in part at the 77th Annual Meeting of the American Society for Clinical Investigation, Washington, D.C., May 1986, and also appeared in abstract form (1986. Clin. Res. 34).

Address reprint requests to Dr. Gigli, Division of Dermatology/ H-81 1J, UCSD Medical Center, 225 Dickinson St., San Diego, CA 92103. Received for publication 24 October 1986.

1. Abbreviations used in this paper: C4d-GPS, complement 4-deficient guinea pig serum; C2d-HS, C2-deficient human serum; C8d-HS, congenital deficiency of $\mathrm{C} 8 \beta$-chain HS; $\mathrm{CH} 50$, total hemolytic activity of HS; EA, sheep erythrocytes sensitized with rabbit anti-sheep hemolysin; EACî-7, EA carrying Cī to C7; GL, Giardia lamblia; NHS, normal HS; SGL, sensitized GL; SGLC5b-7, SGL carrying C5b to C7; VBS, veronalbuffered saline.

J. Clin. Invest.

(c) The American Society for Clinical Investigation, Inc.

0021-9738/87/05/1296/07 \$1.00

Volume 79, May 1987, 1296-1302 been reported, the high incidence of giardiasis observed in immunoglobulin-deficient patients (8) suggested that the humoral immune response may play an important role in resistance to infection with this parasite.

It has recently been reported that the trophozoite stage of GL is susceptible to lysis by human complement in a reaction that involves the activation of the classical pathway of complement and factor(s) specifically absorbable by GL, presumably antibodies $(9,10)$. Moreover, the giardiacidal activity of different sera correlated with the titer of serum IgG antibodies to fixed trophozoites demonstrated by indirect immunofluorescence (10). The present study demonstrates that GL trophozoites sensitized with purified antibodies of the IgM class against GL surface antigens (Deguchi, M., F. D. Gillin, and I. Gigli, manuscript in preparation) are killed by proteins of the complement system. Although activation of the classical pathway is readily demonstrated, we have identified a unique pathway of complement activation in this system that requires $\mathrm{Ca}^{++}$and the complement components $\mathrm{Cl}$ and factor $\mathrm{B}$, but is independent of $\mathrm{C} 2$ and $\mathrm{C} 4$. In addition, lysis of GL trophozoites can be accomplished in the absence of C9.

\section{Methods}

Sera. Human sera were obtained from patients with symptomatic giardiasis, individuals from endemic areas, and from healthy adult donors. Complement-deficient sera were obtained from a homozygous C2-deficient individual (C2d-HS) and from a patient with a congenital deficiency of C8 $\beta$-chain (C8d-HS).

C4-deficient guinea pig serum (C4d-GPS) was obtained from a colony of guinea pigs genetically deficient in $\mathrm{C} 4$. All sera were aliquoted and stored at $-70^{\circ} \mathrm{C}$ until used.

Parasites. GL trophozoites, WB strain (American Type Culture Collection No. 30957) were used for all studies. They were grown at $37^{\circ} \mathrm{C}$ for $24 \mathrm{~h}$ in filter-sterilized-Diamond TYI-S-33 medium (11) with $10 \%$ heat-inactivated adult bovine serum and $1 \%$ fetal calf serum, then modified by adding bovine bile $(500 \mu \mathrm{g} / \mathrm{ml}$, bacteriological use; Sigma Chemical Co., St. Louis, MO), doubling the cysteine concentration (12), and omitting the ferric ammonium citrate, vitamin mixture, and antibiotics. The trophozoites were enumerated by counting in a hemocytometer.

Functional assays for complement proteins. Sheep erythrocytes were sensitized with rabbit anti-sheep hemolysin (EA). EACī,4b cells were generated by incubating EA cells with human serum treated with 100 $\mathrm{mg} / \mathrm{ml}$ of methylprednisolone at $0^{\circ} \mathrm{C}$ for $30 \mathrm{~min}$ (13). EAC4b cells were prepared by treating EACí,4b twice at $37^{\circ} \mathrm{C}$ for $30 \mathrm{~min}$ with veronalbuffered saline (VBS) containing $0.04 \mathrm{M}$ EDTA and $0.1 \%$ gelatin. Sensitized sheep erythrocytes carrying $C \overline{1}$ to $C 7$ (EACī-7) were prepared by incubating EA cells with C8-depleted human serum (see below) at a dilution of $1: 30$.

The total hemolytic activity of human serum (CH50) was determined by incubating EA cells with dilutions of the serum. The samples were incubated $60 \mathrm{~min}$ at $37^{\circ} \mathrm{C}$, the unlysed erythrocytes were removed by centrifugation, and the hemoglobin in the supernatant was measured spectrophotometrically at $\mathrm{OD}_{414}(14)$.

$\mathrm{C} 1$ titration was performed by incubating EAC4b cells with dilutions of the samples to be tested at $30^{\circ} \mathrm{C}$ for $30 \mathrm{~min}$. The extent of EACī,4b 
intermediate formation was measured by incubating the mixture with $\mathrm{C} 20 x y(50 \mathrm{U} / \mathrm{ml})$ for $15 \mathrm{~min}$ at $30^{\circ} \mathrm{C}$; guinea pig serum diluted $1: 15$ in VBS containing $0.01 \mathrm{M}$ EDTA and $0.1 \%$ gelatin was then added and the mixture further incubated at $37^{\circ} \mathrm{C}$ for $60 \mathrm{~min}(15)$.

The titers of $\mathrm{Cl}$ subcomponents $\mathrm{Clq}, \mathrm{Cl}$, and $\mathrm{Cls}$ were determined by incubating EAC4b cells with dilutions of the individual sample to be tested in the presence of excess amounts of the other two subcomponents: $\mathrm{Clr}$ and $\mathrm{Cls}$ for $\mathrm{Clq}, \mathrm{Clq}$ and $\mathrm{Cls}$ for $\mathrm{Clr}$, and $\mathrm{Clq}$ and $\mathrm{Clr}$ for Cls. The extent of $\mathrm{EAC} \overline{1}, 4 \mathrm{~b}$ intermediate formation was measured as described above (16).

C8 was titrated by incubating EACī-7 cells with dilutions of samples at $37^{\circ} \mathrm{C}$ for $60 \mathrm{~min}$ in the presence of $200 \mathrm{CH} 50 \mathrm{U} / \mathrm{ml}$ of $\mathrm{C} 9$ (Cordis Laboratories, Inc., Miami, FL). The unlysed cells were removed by centrifugation, and the extent of lysis was measured spectrophotometrically at $\mathrm{OD}_{414}$.

The total alternative pathway hemolytic activity ( $\mathrm{ACH} 50)$ was determined by incubating rabbit erythrocytes with dilutions of serum samples in VBS containing $0.01 \mathrm{M}$ EGTA, $0.004 \mathrm{M} \mathrm{MgCl}_{2}$, and $0.1 \%$ gelatin at $37^{\circ} \mathrm{C}$ for $30 \mathrm{~min}$. The reaction was stopped with cold $0.01 \mathrm{M}$ EDTAVBS, unlysed erythrocytes were removed by centrifugation, and the hemoglobin in the supernatant was measured (17). Factor B was titrated using rabbit erythrocytes and human serum depleted of factor B activity by heating at $50^{\circ} \mathrm{C}$ for $20 \mathrm{~min}(18)$.

Complement and complement components. Human serum was depleted of a specific complement component protein by immunoabsorption using the IgG fraction of anti-sera prepared against that component (Atlantic Antibodies, Scarborough, ME) coupled to cyanogen bromideactivated Sepharose 4B (Sigma Chemical Co.).

Serum depleted of $\mathrm{Clq}$ was prepared from either normal human serum (NHS) or C2d-HS containing 5 mM EDTA by one passage over an anti-Clq Sepharose 4B column. The effluent was collected, concentrated to the original volume, and brought to $10 \mathrm{mM} \mathrm{CaCl}_{2}$ and $5 \mathrm{mM}$ $\mathrm{MgCl}_{2}$. Measured by quantitative hemolytic assay, the resulting serum contained $<0.01 \%$ of the $\mathrm{Cl}$ activity of the original material. Full hemolytic activity was restored by adding $200 \mu \mathrm{g} / \mathrm{ml}$ of purified Clq. One passage of the Clq depleted serum over an anti-C1r-Cls Sepharose 4B column removed $>99.9 \%$ of $\mathrm{Clr}$ and $\mathrm{Cls}$ activity from the original serum as measured by quantitative hemolytic assay. Full hemolytic activity was reconstituted by adding either purified $\mathrm{Cl}$ or purified subcomponents: $200 \mu \mathrm{g} / \mathrm{ml}$ of Clq, $70 \mu \mathrm{g} / \mathrm{ml}$ of $\mathrm{Clr}$, and $70 \mu \mathrm{g} / \mathrm{ml} \mathrm{of} \mathrm{C1s.} \mathrm{The}$ alternative pathway activity in $\mathrm{C} 2 \mathrm{~d}-\mathrm{HS}$ depleted of $\mathrm{Cl}$ was the same as that of C2d-HS. Factor B activity of both the C2d-HS and C1-depleted C2d-HS was $75 \%$ of that found in NHS.

C2d-HS was depleted of factor B by passing the serum containing 5 mM EDTA once over an anti-factor B Sepharose $4 B$ column. C8-depleted NHS was prepared in the same manner using an anti-C8 Sepharose 4B column. The effluents were concentrated to the original volume and reconstituted to $10 \mathrm{mM} \mathrm{CaCl}_{2}$ and $5 \mathrm{mM} \mathrm{MgCl}_{2}$. The resulting depleted sera contained $<0.01 \%$ activity of the depleted protein compared with the original sera. Full hemolytic activity was restored by adding the purified corresponding components $(300 \mu \mathrm{g} / \mathrm{ml}$ of factor B and $100 \mu \mathrm{g} / \mathrm{ml}$ of C8).

Human Clq, proenzyme C1r, and Cls were gifts from Dr. R. J. Ziccardi (Scripps Clinic and Research Foundation, La Jolla, CA), and human C8 was a gift from Dr. H. J. Müller-Eberhard (Scripps Clinic and Research Foundation). These reagents were biochemically pure as assessed by sodium dodecyl sulfate-polyacrylamide gel electrophoresis analysis. Human $\mathrm{C} 2$ and $\mathrm{C} 9$ were purchased from Cordis Laboratories and factor B from Cytotech, San Diego, CA.

Labeling of C8. Purified C8 was radiolabeled with ${ }^{125}$ I using iodogen (Pierce Chemical Co., Rockford, IL) according to the method of Fraker and Speck (19). The labeled protein contained $2 \times 10 \mathrm{cpm} / \mu \mathrm{g}$ of protein and retained $50 \%$ of its initial hemolytic activity.

Serum-killing assay. The growth medium and nonattached parasites of actively growing GL cultures were discarded, and the parasites were dislodged from the walls of culture tubes by immersion for $10 \mathrm{~min}$ in ice-cold VBS ( $145 \mathrm{mM} \mathrm{NaCl} / 5 \mathrm{mM}$ sodium barbitol) containing $0.1 \%$ bovine serum albumin (BSA), $0.15 \mathrm{mM} \mathrm{CaCl}_{2}$, and $1 \mathrm{mM} \mathrm{MgCl}_{2}\left(\mathrm{VBS}^{++}\right.$.
$0.1 \% \mathrm{BSA}$ ), pH 7.4. The GL were washed in $\mathrm{VBS}^{++}-0.1 \%$ BSA, resuspended in the same buffer, and counted. The killing activity of fresh whole human serum, presumably containing antibodies and complement, was assayed as follows: Aliquots containing $5 \times 10^{5}$ parasites were centrifuged, and the pellets were resuspended and incubated at $37^{\circ} \mathrm{C}$ for 30 min with $125 \mu$ l of the serum to be tested diluted 1:5 in $\mathrm{VBS}^{++}-0.1 \%$ BSA. Viability was determined by the exclusion of trypan blue or acridine orange-ethidium bromide. The percent of lysed parasites was calculated by counting more than $200 \mathrm{GL}$. Evaluation of the participation of antibodies and complement in the reaction was performed in a two-step procedure: GL were sensitized by incubation at $0^{\circ} \mathrm{C}$ for $1 \mathrm{~h}$ with either $125 \mu \mathrm{l}$ of a 1:5 dilution of patient serum in VBS containing $10 \mathrm{mM}$ EDTA (EDTA-VBS) or with purified IgM ( $50 \mu$ in $\left.\mathrm{VBS}^{++}-0.1 \% \mathrm{BSA}\right)$ from this serum. The sensitized GL were washed twice with $\mathrm{VBS}^{++}-0.1 \%$ BSA, and $125 \mu$ l of either 1:5 dilution of NHS or serum deficient in a given complement protein was added. The mixtures were further incubated at $37^{\circ} \mathrm{C}$ for 30 min and the percent of dead GL was determined.

Purification of anti-GL antibodies. $20 \mathrm{ml}$ of human serum with high GL-killing activity was dialyzed for $24 \mathrm{~h}$ against 2 liters of $0.01 \mathrm{M}$ Tris buffer containing $0.1 \mathrm{M} \mathrm{NaCl}$ and $0.005 \mathrm{M}$ EDTA, pH 8.6, and applied to a DEAE Sephadex A50 column $(2.6 \times 40 \mathrm{~cm})$ equilibrated with the same buffer. The column was washed and the protein was eluted with a $\mathrm{NaCl}$ gradient containing $500 \mathrm{ml}$ of wash buffer and $500 \mathrm{ml}$ of the same buffer with $0.25 \mathrm{M} \mathrm{NaCl}$. The eluted fractions were analyzed for killing activity in the presence of NHS as complement source. The active fractions were pooled, concentrated to $2 \mathrm{ml}$ by ultrafiltration (Amicon Corp., Scientific Sys. Div., Danvers, MA), dialyzed against VBS containing 5 mM EDTA, pH 7.4, and chromatographed on a Sepharose 6B column $(1.5 \times 100 \mathrm{~cm})$ equilibrated with the same buffer. The fractions with killing activity were pooled and used as the source of antibodies against GL. This pool contained primarily immunoglobulin of the IgM class, but traces of IgA, $\alpha 2$-macroglobulin, and $\mathrm{C} 4$ binding protein were detected using the corresponding monospecific antibodies.

Preparation of sensitized GL (SGL) carrying C5b to C7 (SGLC5b7). SGLC5b-7 were prepared as follows: $5 \times 10^{5} \mathrm{GL}$ were incubated for $1 \mathrm{~h}$ at $0^{\circ} \mathrm{C}$ with $50 \mu \mathrm{g}$ of IgM purified from a patient's serum in a volume of $100 \mu \mathrm{l}$ with $\mathrm{VBS}^{++}-0.1 \%$ BSA. After washing at $0^{\circ} \mathrm{C}$ with the same buffer, the SGL were further incubated at $37^{\circ} \mathrm{C}$ for 30 min with $150 \mu \mathrm{l}$ of $\mathrm{C} 8$-depleted serum diluted 1:10. The plasma membrane of the parasites at this step of complement activation was intact as shown by its capacity to exclude trypan blue.

C5 to C8 were detected on SGLC5b-7 or SGL using the following immunofluorescence techniques: $5 \times 10^{5}$ of SGLC5b-7 prepared as above or SGL were incubated at $0^{\circ} \mathrm{C}$ for $30 \mathrm{~min}$ with $50 \mu \mathrm{l}$ of fluorescein isothiocyanate-conjugated goat IgG anti-human C5 or C8 (Atlantic Antibodies) diluted 1:5 in $\mathrm{VBS}^{++}-0.1 \%$ BSA. The presence of $\mathrm{C} 6$ and $\mathrm{C} 7$ on SGLC5b-7 or SGL was demonstrated by incubating the parasites at $0^{\circ} \mathrm{C}$ for 30 min with $50 \mu$ of goat antisera monospecific for human $\mathrm{C} 6$ or C7 (Miles Laboratories, Inc., Elkhart, IN) diluted 1:10 in $\mathrm{VBS}^{++}-0.1 \%$ BSA. After washing the parasites were further incubated at $0^{\circ} \mathrm{C}$ for 30 min with $50 \mu \mathrm{l}$ of fluorescein isothiocyanate-conjugated rabbit antigoat immunoglobulin (Atlantic Antibodies) diluted 1:5 in $\mathrm{VBS}^{++}-0.1 \%$ BSA. The parasites were observed under fluorescence microscopy after washing. Throughout these procedures the GL remained viable.

\section{Results}

Participation of $C 1$ and factor $B$ in the killing of $S G L$. When the parasites were incubated with NHS or C2d-HS without sensitizing antibody, only $2-6 \%$ of the GL in the reaction mixture were killed, in agreement with the observation of Hill et al. (9). In contrast, $86 \%$ of GL sensitized with the IgM-containing pool isolated from patient serum were killed by NHS. Incubation of SGL with C2d-HS produced $50 \%$ killing, and addition of $\mathrm{C} 2$ to this reaction mixture increased killing to the same value as that seen with NHS. Neither NHS nor C2d-HS in the presence of 
Table I. Killing of GL Trophozoites by NHS, C2d-HS, or Serum Chelated with EDTA or Mg-EGTA

\begin{tabular}{lc}
\hline & GL killed \\
\hline & $\%$ \\
GL + NHS & 6 \\
SGL + buffer & 5 \\
SGL + NHS & 86 \\
SGL + NHS-EDTA & 1 \\
SGL + NHS-Mg EGTA & 4 \\
GL + C2d-HS & 2 \\
SGL + C2d-HS & 50 \\
SGL + C2d-HS + C2 & 85 \\
SGL + C2d-HS-Mg EGTA & 4 \\
SGL + C2d-HS-Mg EGTA + C2 & 4
\end{tabular}

SGL were prepared by incubation of GL $\left(5 \times 10^{5}\right)$ with $50 \mu \mathrm{g}$ of purified IgM at $0^{\circ} \mathrm{C}$ for $1 \mathrm{~h}$. GL or SGL were reacted at $37^{\circ} \mathrm{C}$ for $30 \mathrm{~min}$ with a source of complement. The percent killing was calculated by counting dye exclusion in a total of 200 parasites.

EDTA- or Mg-EGTA supported killing of SGL above the basal level observed with buffer alone (Table I).

Both normal guinea pig serum and C4d-GPS at a 1:5 dilution killed 15-18\% of GL independently of the presence of sensitizing antibodies. Sensitization of GL before the addition of normal guinea pig serum or C4d-GPS produced 70 and $40 \%$ killing, respectively, while chelation with Mg-EGTA prevented the cytolysis of sensitized GL (Table II).

The observation that C2- and C4-deficient sera support the lysis of SGL suggests the participation of the alternative pathway of complement activation. However, the inhibition observed in the presence of $\mathrm{Mg}$-EGTA indicates a requirement for a $\mathrm{Ca}^{++}$. dependent step in this reaction. Therefore, the role of $\mathrm{Cl}$, a $\mathrm{Ca}^{++}$-dependent component in the complement sequence, was investigated using either NHS or C2d-HS depleted of C1q (Table III). SGL were not lysed when they were incubated with either NHS or C2d-HS depleted of C1q. Addition of purified C1q to Clq-depleted sera totally restored the killing potential of these sera.

We then investigated the contribution of each $\mathrm{Cl}$ subcomponent in a reaction mixture containing SGL and C1-depleted sera (Table IV). While 86 and 58\% killing were obtained with untreated NHS and C2d-HS, respectively, no killing was obtained with the sera depleted of $\mathrm{Cl}$. Although reconstitution was not accomplished by either $\mathrm{Clq}$ alone, $\mathrm{Clq}$ and $\mathrm{Clr}$, or $\mathrm{Cl}$ and

Table II. Killing of Sensitized or Control GL Trophozoites by C4d-GPS

\begin{tabular}{ll}
\hline & GL killed \\
\hline & $\%$ \\
GL + NGPS & 15 \\
SGL* + NGPS & 70 \\
SGL + NGPS-Mg EGTA & 11 \\
GL + C4d-GPS & 18 \\
SGL + C4d-GPS & 40 \\
SGL + C4d-GPS-Mg EGTA & 13
\end{tabular}

NGPS, Normal guinea pig serum.

* Sensitized with IgM purified from immune human serum.
Table III. Participation of Clq in Killing of SGL by Human Serum

\begin{tabular}{lc}
\hline & GL killed \\
\hline & $\%$ \\
SGL + NHS & 77 \\
SGL + NHS/Clq depleted & 9 \\
SGL + NHS/Clq depleted + Clq & 70 \\
SGL + C2d-HS & 35 \\
SGL + C2d-HS/Clq depleted & 5 \\
SGL + C2d-HS/Clq depleted + C1q & 35 \\
\hline
\end{tabular}

$5 \times 10^{5} \mathrm{SGL}$ were incubated at $37^{\circ} \mathrm{C}$ for $30 \mathrm{~min}$ with $125 \mu \mathrm{l}$ of NHS, NHS depleted of C1q, C2d-HS, or C2d-HS depleted of C1q at a 1:5 dilution in $\mathrm{VBS}^{++}-0.1 \%$ BSA. NHS or C2d-HS depleted of C1q was reconstituted with $5 \mu \mathrm{g}$ of purified $\mathrm{Clq}$.

$\mathrm{Cls}$, addition of highly purified $\mathrm{Clq}, \mathrm{Clr}$, and $\mathrm{Cls}$ reconstituted the lytic potential of the C1-depleted sera (Table IV). These results indicate that all the subcomponents of $\mathrm{Cl}(\mathrm{Clq}, \mathrm{r}, \mathrm{s})$ are required for lysis of SGL by either NHS or C2d-HS.

The observation that the electrophoretic mobility of factor $B$ in the supernatant of these reactions was altered in intact sera but not in C1-depleted sera (not shown) prompted studies to evaluate the participation of the alternative pathway in this system. C2d-HS lost its capacity to mediate killing of SGL when it was depleted of factor B (Fig. 1). Addition of increasing amounts of factor B led to a dose-dependent increase in the killing of SGL. In the same experiment, addition of factor B to C2d-HS also increased the lysis of SGL from 50 to $75 \%$. As previously mentioned, the C2d-HS used in this experiment contained $75 \%$ of the functional activity of factor B found in NHS. It can be concluded that while $\mathrm{C} 4$ and $\mathrm{C} 2$ are not necessary in the events leading to lysis of SGL, lysis requires both intact $\mathrm{Cl}$ and components of the alternative pathway.

Participation of late-acting complement components $C 8$ and

Table IV. Participation of CI in Killing of SGL by Human Serum

\begin{tabular}{lc}
\hline & GL killed \\
\hline & $\%$ \\
SGL + NHS & 84 \\
SGL + NHS/C1 depleted & 3 \\
+ C1q & 5 \\
+ C1q, C1r & 10 \\
+ C1r, C1s & 6 \\
+ C1q, C1r, C1s & 84 \\
SGL + C2d-HS & 58 \\
SGL + C2d-HS/C1 depleted & 1 \\
+ C1q & 3 \\
+ C1q, C1r & 8 \\
+ C1r, C1s & 1 \\
+ C1q, C1r, C1s & 40 \\
\hline
\end{tabular}

$5 \times 10^{5} \mathrm{SGL}$ were incubated at $37^{\circ} \mathrm{C}$ for $30 \mathrm{~min}$ with $125 \mu \mathrm{l}$ of NHS, NHS depleted of $\mathrm{C1}, \mathrm{C2d}-\mathrm{HS}$, or C2d-HS depleted of $\mathrm{C1}$ at a 1:5 dilution in $\mathrm{VBS}^{++}-0.1 \%$ BSA. NHS or C2d-HS depleted of $\mathrm{Cl}$ was reconstituted with purified factors: $5 \mu \mathrm{g}$ of $\mathrm{Clq}, 1.7 \mu \mathrm{g}$ of $\mathrm{Clr}$, and $1.5 \mu \mathrm{g}$ of C1s. 


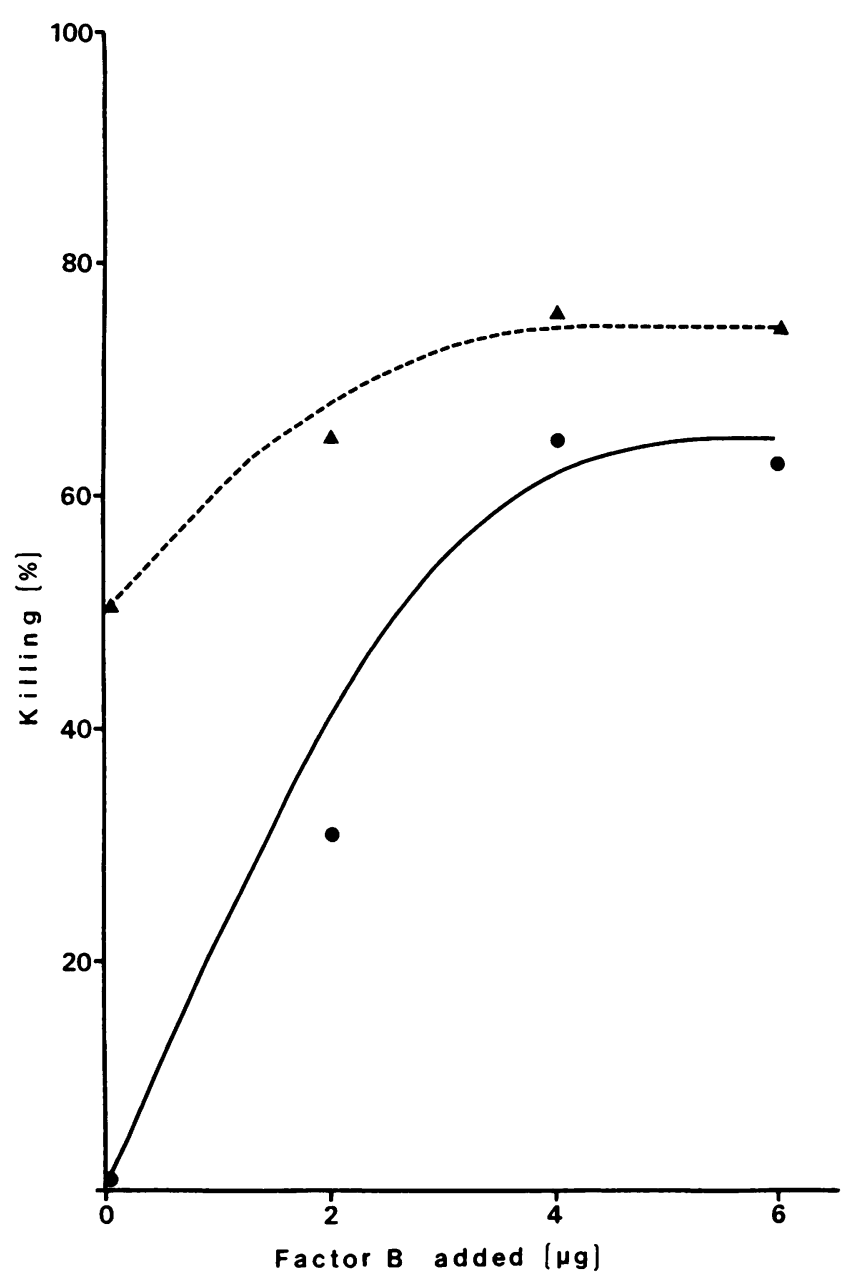

Figure 1. Participation of factor B in killing of SGL by C2d-HS. Increasing amounts of factor B $(2-6 \mu \mathrm{g})$ were added to $5 \times 10^{5} \mathrm{SGL}$ in $125 \mu \mathrm{l}$ of 1:5 diluted C2d-HS (solid triangle) or C2d-HS depleted of factor B (solid circle) in $\mathrm{VBS}^{++}-0.1 \%$ BSA. The reaction mixtures were incubated at $37^{\circ} \mathrm{C}$ for $30 \mathrm{~min}$.

C9 in the killing of SGL. SGLC5b-7 were prepared using purified IgM from anti-GL patient serum and C8-depleted normal serum. That this intermediate carried $\mathrm{C} 5 \mathrm{~b}$ to $\mathrm{C} 7$, but not $\mathrm{C} 8$, was confirmed by direct and indirect immunofluorescence using monospecific antibodies to $\mathrm{C} 5, \mathrm{C} 6, \mathrm{C} 7$, and $\mathrm{C} 8$.

SGLC5b-7 were further incubated with either buffer alone, $\mathrm{C} 8$ or $\mathrm{C} 9$, or both $\mathrm{C} 8$ and $\mathrm{C} 9$ (Table $\mathrm{V}$ ). The addition of $\mathrm{C} 8$ $(100 \mathrm{ng})$ alone increased killing to $56 \%$. The addition of $\mathrm{C} 9(100$ $\mathrm{CH} 50 \mathrm{U}$ ) in the presence of the same amount of $\mathrm{C} 8$ further increased killing to $93 \%$, while $C 9$ alone was without effect. To exclude the possibility that trace amounts of $\mathrm{C} 9$ either in the $\mathrm{C} 8$ preparation or bound to the parasite during the formation of the intermediates could account for the killing observed in the absence of $\mathrm{C} 9$, the $\mathrm{C} 8$ preparation was added to the reaction mixture in the presence of IgG anti-human C9 (Table IV). The number of parasites killed was the same in the presence and absence of anti-C9.

To determine whether the increase in lysis of GL noted with C8 plus C9 was due to an increased uptake of C8 under these experimental conditions, an experiment was performed using ${ }^{125} \mathrm{I}$-labeled $\mathrm{C} 8$. Increasing amounts of ${ }^{125} \mathrm{I}-\mathrm{C} 8(50-400 \mathrm{ng})$ alone or with a constant amount of $\mathrm{C} 9(100 \mathrm{CH} 50 \mathrm{U})$ were added to
Table V. Participation of Late-acting Complement Components $C 8$ and $C 9$ in Killing of SGL

\begin{tabular}{lc}
\hline & GL killed \\
\hline & $\%$ \\
GL + C8d-HS & 2 \\
SGL + C8d-HS & 4 \\
SGL + C8d-HS + C8 & 90 \\
SGLC1-7 + buffer & 9 \\
SGLC1-7 + C8 & 56 \\
SGLC1-7 + C9 & 3 \\
SGLC1-7 + C8 + C9 & 93 \\
SGLC1-7 + C8 + anti-C9 & 58
\end{tabular}

$5 \times 10^{5}$ GL or SGL were incubated with $125 \mu$ of C8d-HS diluted 1:5 in $\mathrm{VBS}^{++}-0.1 \%$ BSA with or without purified C8 (100 ng). SGLC5b-7 intermediate cells were prepared by incubation of $5 \times 10^{5} \mathrm{SGL}$ with $125 \mu \mathrm{l}$ of C8d-HS diluted $1: 10$ in $\mathrm{VBS}^{++}-0.1 \%$ BSA. $5 \times 10^{5}$ SGLC $5 \mathrm{~b}-$ 7 were incubated with $\mathrm{C} 8(100 \mathrm{ng})$ alone, $\mathrm{C} 9$ (100 CH50 U) alone, C8 and $\mathrm{C}$, or $\mathrm{C} 8$ and anti-C9 antibody.

SGLC5b-7 (Fig. 2), and bound and free ${ }^{125}$ I-C8 were separated by centrifugation of the reaction mixture. As shown in Fig. 2, ${ }^{125} \mathrm{I}-\mathrm{C} 8$ was bound to SGLC5b-7 in proportion to the amounts of ${ }^{125} \mathrm{I}-\mathrm{C} 8$ added. There was no difference in the binding of $\mathrm{C} 8$ in the presence and absence of $\mathrm{C}$.

The relationship between $\mathrm{C} 8$ binding to SGLC5b-7 and killing of the parasites was next investigated (Fig. 3). Several dilutions of ${ }^{125}$ I-radiolabeled $\mathrm{C} 8$ alone, or $\mathrm{C} 8$ and $\mathrm{C} 9$ were reacted with SGLC5b-7, and the amounts of bound C8 counted and related to percent killing. The killing of SGLC5b-7 increased with the number of $\mathrm{C} 8$ molecules bound in the absence of $\mathrm{C} 9$ until it reached $50 \%$, when $50,000 \mathrm{C} 8$ molecules per cell were bound. In contrast, in the presence of $\mathrm{C} 9,<4,000$ molecules of bound C8 caused maximal killing (80\%). That percent killing in the absence of C9 didn't increase when bound C8 increased more than twice suggested that the kinetics of killing by $\mathrm{C} 8$ alone differ from those of $\mathrm{C} 8$ with $\mathrm{C}$. This was investigated using SGLC5b-7 incubated with four increasing concentrations of C8 (Fig. 4). To a duplicate sample with the lowest concentration of C8, C9 was added. The percent of GL killed was assessed at time intervals. Maximal killing was observed at $30 \mathrm{~min}$ in the presence of $\mathrm{C} 8$ and $\mathrm{C} 9$ at a $\mathrm{C} 8$ input in the mixture of 90,000 molecules per cell. The same amount of $\mathrm{C} 8$ in the absence of C9 showed $<10 \%$ killing even at $120 \mathrm{~min}$. However, by increasing the concentration of added $\mathrm{C} 8$, a gradual increase in killing of SGLC5b-7 was noted. When eight times more C8 was used, lysis of the parasite comparable to that obtained with the lowest concentration of $\mathrm{C} 8$ in the presence of $\mathrm{C} 9$ was obtained in $120 \mathrm{~min}$.

\section{Discussion}

The data presented here demonstrate that the lysis of GL trophozoites sensitized with specific antibodies to the parasites requires activation of the complement system.

The observation that the killing of IgM-sensitized GL was accomplished with NHS, C4-, and C2-deficient serum, but not with the above sera in Mg-EGTA or depleted of C1, suggested that in addition to the classical pathway, the sensitized parasite 


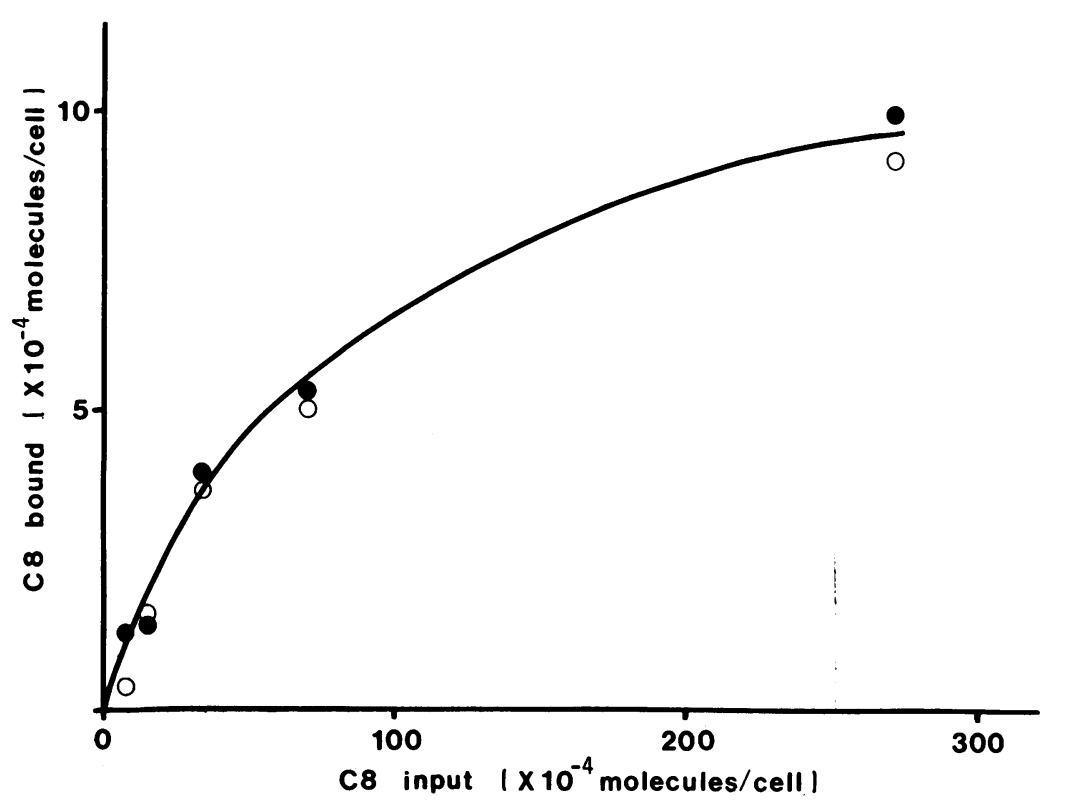

Figure 2. ${ }^{125} \mathrm{I}-\mathrm{C} 8$ uptake by SGLC5b-7 in the presence (open circle) or absence (solid circle) of $\mathrm{C} 9.5 \times 10^{5}$ SGLC5b-7 were incubated with ${ }^{125} \mathrm{I}-\mathrm{C} 8(50-400 \mathrm{ng})$ alone or in the presence of constant amounts of $\mathrm{C} 9$ $(100 \mathrm{CH} 50 \mathrm{U})$ in $125 \mu \mathrm{l}$ of $\mathrm{VBS}^{++}-0.1 \%$ BSA. After incubation at $0^{\circ} \mathrm{C}$ for $30 \mathrm{~min}$, the cell suspensions were layered onto $200 \mu \mathrm{l}$ of a Kodak dibutylphthalate/ dioctylphthalate mixture (6:4 vol, respectively) in 400$\mu \mathrm{l}$ Bio-Rad polypropylene tubes. The tubes were centrifuged for $1 \mathrm{~min}$ at $8,000 \mathrm{~g}$ in a Beckman microfuge, cut, and bound and free $\mathrm{C} 8$ were measured in the pellets and supernatants. Specific ${ }^{125} \mathrm{I}-\mathrm{C} 8$ bound was calculated by substracting the nonspecific uptake by the SGL. could be lysed by the activation of a unique pathway that required $\mathrm{Cl}$ and $\mathrm{Ca}^{++}$but was independent of the classical pathway components $\mathrm{C} 2$ and $\mathrm{C} 4$.

Further investigation of the participation of $\mathrm{Cl}$ in this reaction showed that the three subcomponents of $\mathrm{Cl}, \mathrm{Clq}, \mathrm{Clr}$, and $\mathrm{Cls}$, are required for the initial activation of this pathway. This initial activation of $\mathrm{Cl}$ leads into the alternative pathway as indicated by the observation that there is cleavage of factor $B$ in this reaction. This was further supported by showing that depletion of factor B abrogated killing, and reconstitution with highly purified factor B reestablished the lytic potential of sera in a dose-response manner. These studies expand the observation of Hill et al. (9), who found that factor B was not depleted by GL in Mg-EGTA chelated serum. In addition, these findings are consistent with the previous reports by May et al. showing that heavily sensitized sheep erythrocytes were lysed by C4dGPS or C2d-HS in a reaction that required $\mathrm{Cl}$ or a C1-like protein and the alternative pathway (20-22).

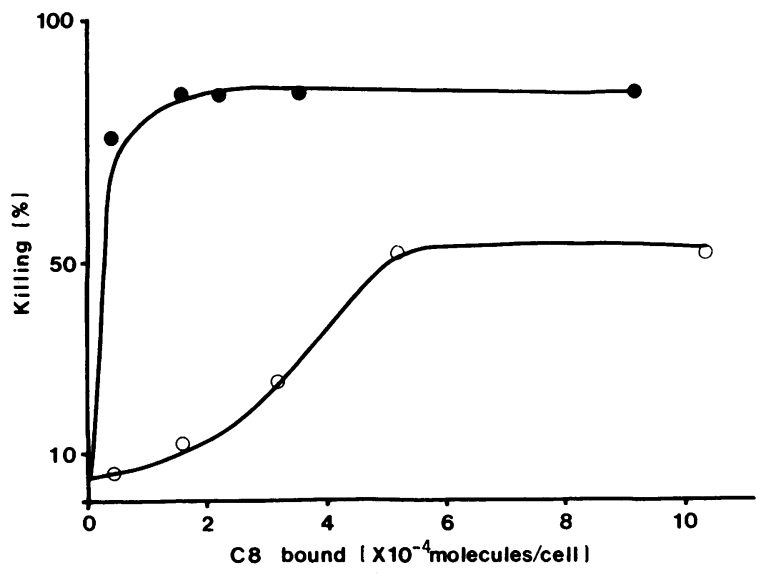

Figure 3. Relationship between killing of SGLC5b-7 and ${ }^{125} \mathrm{I}-\mathrm{C} 8$ uptake. SGLC5b-7 were incubated at $37^{\circ} \mathrm{C}$ for 30 min with several dilutions of ${ }^{125} \mathrm{I}-\mathrm{C} 8$ alone (open circle), or with $\mathrm{C} 8$ and $\mathrm{C} 9$ (100 CH50 U) (solid circle). The number of $\mathrm{C} 8$ molecules were measured based on ${ }^{125} \mathrm{I}-\mathrm{C} 8$ uptake.
Although the molecular events in this pathway are still unclear, our study demonstrates that a nucleated cell can be lysed by specific antibodies and the alternative pathway utilizing $\mathrm{Cl}$ for its initial activation. Our data differ from those of Hill et al. (9), who did not observe killing of GL by C2d-HS. The difference may be that the present studies utilized a two-stage procedure in which GL trophozoites were sensitized with antibodies and washed before exposure to complement.

The data on the participation of the late-acting complement components in the killing of SGL showed that C5b-8 complexes were sufficient to damage the membrane of GL (Table IV). To confirm that the observed damage of the parasite was caused by C5b-8 complexes, it was necessary to eliminate the possibility that the purified $\mathrm{C} 8$ used in the experiments was contaminated

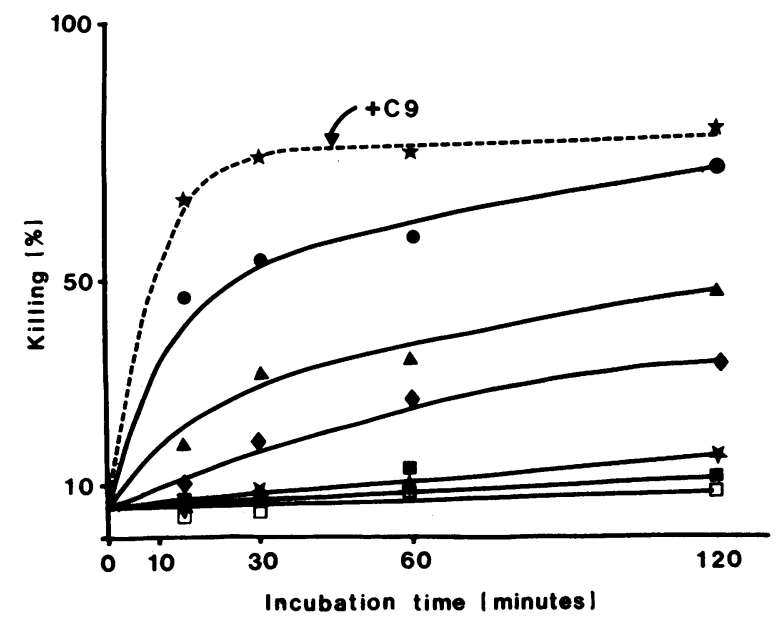

Figure 4. Kinetics of killing of SGLC5b-7 by C8. SGLC5b-7 were incubated at $37^{\circ} \mathrm{C}$ with several concentrations of $\mathrm{C} 8$ in the reaction mixtures ([filled star] $9 \times 10^{4}$ molecules/cell; [filled diamond] 18 $\times 10^{4}$ molecules/cell; [filled triangle] $35 \times 10^{4}$ molecules/cell; and [filled circle] $70 \times 10^{4}$ molecules/cell) in $200 \mu \mathrm{l}$ of $\mathrm{VBS}^{++}-0.1 \% \mathrm{BSA}$. The lowest concentration of $\mathrm{C} 8\left(9 \times 10^{4} / \mathrm{cell}\right)$ was used in the presence of $100 \mathrm{CH} 50 \mathrm{U}$ of $\mathrm{C} 9$. Killing was assessed at the indicated time intervals. (filled square) Buffer; (open square) C9. 
with $\mathrm{C} 9$. The possibility of $\mathrm{C} 9$ contamination in the purified $\mathrm{C} 8$ was assessed by incubating SGLC1-7 with $\mathrm{C} 8$ in the presence of anti-human $\mathrm{C} 9$ antibody. As shown in Table IV, no difference in percent killing of SGLC1-7 by C8 was observed between GL samples incubated in the presence or absence of antibody to C9. An alternative source of contaminating $C 9$ could be the bovine serum used in the medium in which GL were grown. To eliminate this possibility, GL were grown in $10 \%$ heat-inactivated human serum instead of $10 \%$ bovine serum plus $1 \%$ fetal calf serum. These GL were treated with anti-human C9 before sensitizing and they were compared with untreated parasites in their susceptibility to the lytic effect of $\mathrm{C} 8$. There were no differences in percent killing of SGLC1-7 by $\mathrm{C} 8$ between the samples that were pretreated with anti-C9 antibody or with buffer alone (data not shown).

Investigation of the relationship between the number of $\mathrm{C} 8$ molecules bound to the cell surface and the resulting lysis of these cells demonstrated that $\sim 50,000 \mathrm{C} 8$ molecules per cell were required to cause $50 \%$ lysis of SGLC5b-7 in the absence of $\mathrm{C} 9$, while $\sim 4,000 \mathrm{C} 8$ molecules caused the same amount of killing in the presence of $\mathrm{C} 9$. These findings are in close agreement with the results of Morgan et al. (23) using the U937 cell line. Kinetic studies of killing of SGLC $5 \mathrm{~b}-7$ by $\mathrm{C} 8$ showed that the percent of parasites killed by $\mathrm{C} 8$ increased with both the concentration of $\mathrm{C} 8$ and the time of incubation, and that the rate of killing by $\mathrm{C} 8$ was much lower than that of $\mathrm{C} 8$ plus $\mathrm{C}$. These results may be due to differences in functional channel size (24), stability of C5b-8 complexes (25) in the presence and absence of $\mathrm{C} 9$, or capacity of the parasite to repair the damaged membrane.

It has been demonstrated that in general, nucleated cells are more resistant to killing by complement than erythrocytes, and that the C5b-8, which is sufficient to lyse erythrocytes $(26,27)$, cannot lyse certain nucleated cells such as guinea pig hepatoma cells (line 1$)$ or Raji cells $(28,29)$. On the other hand, recent studies showed that C5b-8 was able to initiate lysis of certain bacteria, such as Escherichia coli (30) and Neisseria (31), and of some mammalian cell lines, U937 (23), and melanoma cells (32). In all these studies, greater amounts of $\mathrm{C} 8$ were required to lyse nucleated cells than to lyse erythrocytes. These differences in the sensitivity of nucleated cells to the cytotoxic action of complement may be due to differences in metabolic properties, the chemical and physical composition of the cell membrane (33), and/or the capacity to eliminate complement components from the plasma membrane (34-36). Our studies show that the membrane of the GL trophozoite, a flagellated unicellular organism, does not appear to be capable of resisting the effect of complement-mediated lysis.

The idea that the sensitizing antibody is of the IgM class is supported by several lines of evidence (Deguchi, M., F. D. Gillin, and I. Gigli, manuscript in preparation): Sensitizing activity copurified with IgM on DEAE Sephadex and Sephadex 6B; only IgM, and not IgG or IgA, was observed on the surface of GL reacted with human serum while alive using indirect immunofluorescence, and killing was abrogated in the presence of antibodies to IgM, but not to IgG or IgA. The recent report of Goka et al. (7) that IgM, but not IgG antibodies to GL correlate with infection, agrees with our findings. In contrast, using fixed parasites, Hill et al. $(9,10)$ reported the presence of IgG antibody on GL by an immunoperoxidase method.

All the serum samples with killing activity in our study had anti-Giardia antibodies of the IgM class. However, this sensi- tizing antibody to GL in immune serum could not be detected on sensitized and washed parasites after incubation at $37^{\circ} \mathrm{C}$ for $30 \mathrm{~min}$ (37). The disappearance of the immunoglobulin from the surface of the parasite may be due to dissociation, internalization, or proteolytic degradation of the immunoglobulin. Regardless of the mechanism, it is clear that unless complement activation has reached the $\mathrm{C} 5 \mathrm{~b}$ step, incubation at $37^{\circ} \mathrm{C}$ aborts the lytic effect of complement (Deguchi, M., F. D. Gillin, and I. Gigli, manuscript in preparation). These findings are the basis for our experimental design in which sensitization was performed at $0^{\circ} \mathrm{C}$.

Although GL resides primarily in the lumen of the gut, the lysis of this parasite mediated by antibody and complement may play an important role in the prevention of extension of lesions into the intestinal wall by inducing lysis of any parasites that may invade to the submucosa.

\section{Acknowledgments}

We thank Sue Krayzel for her secretarial help in the preparation of this manuscript and $\mathrm{M}$. Gault for technical help.

This work was supported by grants AM-35108 and AI-20067 from National Institutes of Health.

\section{References}

1. Ridley, M. J., and D. S. Ridley. 1976. Serum antibodies and jejunal histology in giardiasis associated with malabsorption. J. Clin. Pathol. 29: 30-34.

2. Smith, P. D., C. O. Elson, D. B. Keister, and T. E. Nash. 1982. Human host response to Giardia lamblia. I. Spontaneous killing by mononuclear leukocytes in vitro. J. Immunol. 128:1372-1376.

3. Hill, D. R., J. J. Burge, J. L. Harcus, and R. D. Pearson. 1982. Ingestion and killing of Giardia lamblia by human macrophages. Clin. Res. 30:369A. (Abstr.)

4. Smith, P. D., F. D. Gillin, W. R. Brown, and T. E. Nash. 1981. IgG antibody to Giardia lamblia detected by enzyme-linked immunosorbent assay. Gastroenterology. 80:1476-1480.

5. Visvesvara, G. S., P. D. Smith, G. R. Healy, and W. R. Brown 1980. An immunofluorescence test to detect serum antibodies to Giardia lamblia. Ann. Intern. Med. 93:802-805.

6. Thompson, A., R. Rowland, R. Hecker, G. I. Gibson, and D. P Reid. 1977. Immunoglobulin-bearing cells in giardiasis. J. Clin. Pathol. 30:292-294.

7. Goka, A. K. J., D. D. K. Rolston, V. I. Mathan, and M. J. G. Farthing. 1986. Specific IgM antibody response as a diagnostic test for giardiasis. Gastroenterology. 90:1430. (Abstr.)

8. Hermans, P. E., J. A. Diaz-Buxo, and J. D. Stobo. 1976. Idiopathic late onset immunoglobulin deficiency. Am. J. Med. 61:221-237.

9. Hill, D. R., J. J. Burge, and R. D. Pearson. 1984. Susceptibility of Giardia lamblia trophozoites to the lethal effect of human serum. $J$. Immunol. 132:2046-2052.

10. Hill, D. R., and R. Pohl. 1984. Studies on the susceptibility of Giardia lamblia isolates to the lethal effects of huma serum. 33rd Ann. Meet. Am. Soc. Tropical Med. Hygiene, Baltimore. 118.

11. Diamond, L. S., D. Harlow, and C. C. Cunnick. 1978. A new medium for the axenic cultivation of Entamoeba histolytica and other Entamoeba. Trans. R. Soc. Trop. Med. Hyg. 72:431-432.

12. Keister, D. B. 1983. Axenic culture of Giardia lamblia in TY1S-33 medium supplemented with bile. Trans. R. Soc. Trop. Med. Hyg. 77:487-488.

13. Kitamura, F., K. Shimada, T. Suzuki, and K. Nishioka. 1985. A simplified method for the preparation of EAC14 intermediate cells using human serum treated with methylprednisolone. J. Immunol. Methods. 85:363-370.

14. Kabat, E. A., and M. M. Mayer. 1961. Experimental Immunochemistry. Charles C Thomas Publisher, Springfield, IL. 133. 
15. Borsos, T., and H. J. Rapp. 1963. Chromatographic separation of the first component of complement: Assay on a molecular basis. $J$. Immunol. 91:851-858.

16. Lepow, I. H., G. B. Naff, E. W. Todd, T. Pensky, and C. F. Heinz Jr. 1963. Chromatographic resolution of the first component of human complement into three activities. J. Exp. Med. 117:983-1008.

17. Platts-Mills, T. A. E., and K. Ishizaka. 1974. Activation of the alternative pathway of human complement by rabbit cells. J. Immunol. 113:348-358.

18. Lesavre, P. H., T. E. Hugli, A. F. Esser, and H. J. Müller-Eberhard. 1979. The alternative pathway $\mathrm{C} 3 / \mathrm{C} 5$ convertase: Chemical basis of factor B activation. J. Immunol. 123:529-534.

19. Fraker, P. J., and J. C. Speck, Jr. 1978. Protein and cell membrane iodinations with a sparingly soluble chloramide 1,3,4,6-tetrachloro-3a,6adiphenylglycoluril. Biochem. Biophys. Res. Commun. 80:849-857.

20. May, J. E., and M. M. Frank. 1973. Hemolysis of sheep erythrocytes in guinea pig serum deficient in the fourth component of complement. I. Antibody and serum requirements. J. Immunol. 111:16611667.

21. May, J. E., and M. M. Frank. 1973. Hemolysis of sheep erythrocytes in guinea pig serum deficient in the fourth component of complement. II. Evidence for involvement of $\mathrm{Cl}$ and components of the alternative complement pathway. J. Immunol. 111:1668-1676.

22. May, J. E., and M. M. Frank. 1973. A new complement-mediated cytolytic mechanism: the C1-bypass activation pathway. Proc. Natl. Acad. Sci. USA. 70:649-652.

23. Morgan, B. P., D. K. Imagawa, J. R. Dankert, and L. E. Ramm. 1986. Complement lysis of U937, a nucleated mammalian cell line in the absence of C9: Effect of C9 on C5b-8 mediated cell lysis. J. Immunol. 136:3402-3406.

24. Ramm, L. E., M. B. Whitlow, and M. M. Mayer. 1982. Size of the transmembrane channels produced by complement proteins C $5 \mathrm{~b}-8$. J. Immunol. 129:1143-1146.

25. Michaels, D. W., A. S. Abramovitz, C. H. Hammer, and M. M. Mayer. 1978. Characterization of the complement lesion: the formation of transmembrane channels and their mechanism of assembly. J. Immunol. 120:1785. (Abstr.)

26. Stolf, R. L. 1968. Immune lytic transformation: A state of irreversible damage generated as a result of reaction of the eighth component in the guinea pig complement system. J. Immunol. 100:46-54.
27. Tamura, N., A. Shimada, and S. Chang. 1972. Further evidence for immune cytolysis by antibody and the first eight components of complement in the absence of C9. Immunology 22:131-140.

28. Boyle, M. D. P., S. H. Ohanian, and T. Borsos. 1976. Lysis of tumor cells by antibody and complement. VII. Complement-dependent ${ }^{86} \mathrm{Rb}$ release: a nonlethan event? J. Immunol. 117:1346-1350.

29. Schreiber, R. D., M. K. Pangburn, R. G. Medicus, and H. J. Müller-Eberhard. 1980. Raji cell injury and subsequent lysis by the purified cytolytic alternative pathway of human complement. Clin. Immunol. Immunopathol. 15:384-389.

30. Lint, T. F., H. J. Zeitz, and H. Gewurz. 1980. Inherited deficiency of the ninth component of complement in man. J. Immunol. 125:22522257.

31. Harriman, G. R., A. F. Esser, E. R. Podack, A. C. Wunderlich, A. J. Braude, T. F. Lint, and J. G. Curd. 1981. The role of C9 in complement-mediated killing of Neisseria. J. Immunol. 127:2386-2390.

32. Martin, D. E., F. J. Chiu, I. Gigli, and H. J. Müller-Eberhard. 1986. Killing of human melanoma cells by the membrane attack complex of human complement as a function of its molecular composition. Clin. Res. 34:640a. (Abstr.)

33. Ohanian, S. H., and S. I. Schlager. 1981. Humoral immune killing of nucleated cells: Mechanisms of complement-mediated attack and target cell defense. CRC Crit. Rev. Immunol. 2:165-209.

34. Ramm, L. E., M. B. Whitlow, C. L. Koski, M. L. Shin, and M. M. Mayer. 1983. Elimination of complement channels from the plasma membranes of U937, a nucleated mammalian cell line: Temperature dependence of the elimination rate. J. Immunol. 131:14111415.

35. Morgan, B. P., A. K. Campbell, J. P. Luzio, and M. B. Hallett. 1984. Recovery of polymorphonuclear leucocytes from complement attack. Biochem. Soc. Trans. 12:779.

36. Carney, D. F., C. L. Koski, and M. L. Shin. 1985. Elimination of terminal complement intermediates from the plasma membrane of nucleated cells: The rate of disappearance differs for cells carrying C5b7 or C5b-8 or a mixture of C5b-8 with a limited number of C5b-9. J. Immunol. 134:1804-1809.

37. Deguchi, M., J. F. Nicolas, F. Gillin, and I. Gigli. 1985. Sensitization of Giardia lamblia to killing by complement. Clin. Res. 33: 563a. (Abstr.) 